CURRENT BIOCHEMISTRY

ISSN: $2355-7877$

Journal Homepage: http://biokimia.ipb.ac.id

Journal Email: current.biochemistry@ipb.ac.id

\title{
Produksi Asam Laktat dan Pola Pertumbuhan Bakteri Asam Laktat dengan Pemberian Dosis Rendah Propolis Trigona spp asal Pandeglang Indonesia
}

\author{
Akhmad Endang Zainal Hasan*, I Made Artika, Syaeful Abidin \\ Departemen Biokimia, Institut Pertanian Bogor (IPB), Bogor 16680, Indonesia
}

Received: 25 July 2014; Accepted 31 October 2014

*Corresponding author: Dr. Ir. A.E. Zainal Hasan, MSi; Departemen Biokimia, Jl. Agatis Gd. Fapet Lt. 5, Wing 5, Bogor 16680; Telp/Fax.+62251-8423267; Email: zainalhasan@ipb.ac.id; pakzainalhasan@gmail.com.

\begin{abstract}
Propolis is known to have an antimicrobial activity and can prevent various diseases. Propolis consumption is feared to have negative impact on the activity of digestive lactid acid bacteria (LAB). The aim of this research was to examine the effect of propolis on the growth and lactic acid production of three LAB. Ethanol Extraction Propolis (EEP) concentrations examined were control, eep and $X$ propolis $0 \%$ (control), $0.2 \%, 0.6 \%, 1.0 \%$ and $X$ propolis at $0.4 \%$ concentration. The parameters analyzed were the growth of bacteria counted with Total Plate Count (TPC) method and lactic acid production using titrable acidity analysis. Propolis at 0,6\% concentration stimulated the growth of

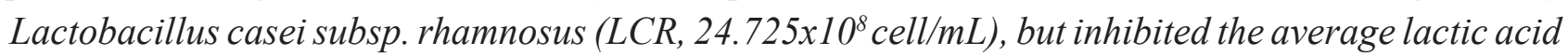
production (0.071\%) lower than control (0,149\%). Propolis did not affect the growth of Streptococcus thermophillus (STP), but propolis at 0,6\% concentration stimulated lactic acid production (0.182\%) higher than control (0.112\%). Propolis inhibited the growth of Lactobacillus delbrueckii subsp. bulgaricus (LDB), but at 0,2\% concentration, its population was still highest $\left(3.775 \times 10^{8} \mathrm{cell} / \mathrm{mL}\right)$ and lactic acid production was stimulated (0.195\%) higher than control (0.123\%).
\end{abstract}

Keywords: lactid acid bacteria, Lactobacillus casei, Lactobacillus delbrueckii, propolis, Streptococcus thermophillus.

\section{ABSTRAK}

Propolis dikenal memiliki aktivitas antimikroba dan dapat mencegah berbagai penyakit. Oleh karena itu, propolis dikhawatirkan berdampak menghambat pertumbuhan bakteri asam laktat (BAL) dalam saluran pencernaan. Tujuan dari penelitian ini adalah untuk menguji pengaruh propolis dosis rendah terhadap pertumbuhan dan produksi asam laktat dari tiga BAL. Propolis yang digunakan adalah propolis ekstrak etanol (EEP) dan propolis X dengan konsentrasi $0 \%$ (kontrol), 0.2\%, 0.6\%, 
1.0\% dan propolis X pada konsentrasi $0.4 \%$. Parameter yang dianalisis adalah pertumbuhan bakteri dihitung dengan Total Plate Count (TPC) dan produksi asam laktat dengan menggunakan metode analisis titrable acidity. Propolis pada konsentrasi $0.6 \%$ merangsang pertumbuhan Lactobacillus casei subsp. rhamnosus (LCR $\left.24.725 \times 10^{8} \mathrm{sel} / \mathrm{mL}\right)$, namun rata-rata produksi asam laktat (0.071\%) dihambat lebih rendah dibandingkan kontrol (0.149\%). Propolis tidak mempengaruhi pertumbuhan Streptococcus thermophillus (STP), namun propolis pada konsentrasi $0.6 \%$ merangsang produksi asam laktat (0.182\%) lebih tinggi dibanding kontrol (0.112\%). Propolis menghambat pertumbuhan Lactobacillus delbrueckii subsp. bulgaricus (LDB), tetapi pada konsentrasi $0.2 \%$ produksinya tertinggi $\left(3.775 \times 10^{8} \mathrm{sel} / \mathrm{mL}\right)$ dan produksi asam laktat dirangsang $(0.195 \%)$ lebih tinggi dibanding kontrol $(0.123 \%)$.

Kata kunci: bakteri asam laktat, Lactobacillus casei, Lactobacillus delbrueckii, propolis,

Streptococcus thermophillus.

\section{PENDAHULUAN}

Propolis merupakan produk terpenting kedua setelah madu yang digunakan lebah sebagai komponen pertahanan, sistem imun eksternal, dan antimikroba. Propolis dikumpulkan oleh lebah madu dari berbagai jenis tumbuhan terutama dari bagian kuncup dan daun. Secara umum, propolis terdiri atas campuran resin 45-55\%, lilin dan asam lemak 23-35\%, minyak atsiri $10 \%$, polen $5 \%$, minyak organik dan mineral 5\% (Fearnley 2001). Lebah menggunakan propolis untuk membangun sarang yang kokoh. Propolis juga berfungsi sebagai komponen sistem pertahanan bagi lebah. Lebah merupakan spesies yang hidup berkelompok $(>50.000$ lebah per kelompok) pada habitat/sarang yang lembab dengan suhu $35{ }^{\circ} \mathrm{C}$. Kondisi sarang seperti itu sangat memungkinkan berbagai mikroorganisme untuk tumbuh, mengkontaminasi sarang, dan menyebabkan penyakit. Adanya propolis menjadikan kondisi sarang tetap aman dan terbebas dari faktor pengganggu (Fearnley 2001).

Penelitian di bidang kesehatan terhadap bahan alam propolis telah banyak dilakukan, baik secara in vitro maupun in vivo. Kembalinya perhatian ke bahan alam ini dianggap sebagai hal yang sangat bermanfaat karena sejak dahulu masyarakat kita percaya bahwa bahan alam mampu mengobati berbagai macam penyakit. Pemanfaatan bahan alam sebagai obat jarang menimbulkan efek samping yang merugikan dibandingkan obat yang terbuat dari bahan sintetis (Sabir 2005a; Sabir 2005b).

Salah satu aplikasi propolis di bidang kesehatan adalah sebagai obat atau suplemen antibakteri yang dapat mencegah dan mengobati berbagai penyakit. Menurut Bankova et al. (2000), propolis dapat menghambat bakteri Gram positif maupun Gram negatif. Mekanisme antibakteri propolis terhadap pertumbuhan berbagai bakteri belum diketahui dengan pasti. Hal ini perlu menjadi perhatian khusus bagi konsumen propolis karena di dalam tubuh manusia juga terdapat ribuan mikroflora alami saluran pencernaan. Bakteri yang berperan menjaga keseimbangan mikroflora usus ini disebut bakteri probiotik. Salah satu produk utama yang dihasilkan bakteri probiotik adalah asam laktat (Sulminen et al. 1999).

Penelitian tentang efek propolis terhadap bakteri probiotik baru dilaporkan beberapa 
tahun terakhir. Fatoni (2008) dan Tukan (2008) melaporkan bahwa ekstrak propolis dapat menghambat pertumbuhan beberapa jenis bakteri probiotik dan patogen yang diisolasi dari usus halus sapi. Konsentrasi hambat tumbuh minimum (KHTM) propolis terhadap bakteri probiotik lebih tinggi daripada terhadap bakteri patogen. Hal ini berarti, propolis lebih bersifat antagonis terhadap bakteri patogen daripada terhadap bakteri probiotik. Hasil yang serupa diperoleh dari penelitian dan Kalogeropoulos et al. (2009) menemukan bahwa propolis asal Yunani dan Cyprus menghambat bakteri patogen tapi tidak menghambat bakteri penghasil asam laktat. Haddadin et al. (2008) melaporkan bahwa propolis memiliki pengaruh berbeda terhadap aktivitas bakteri Bifidobacterium infantis dan Lactobacillus acidophilus, keduanya merupakan bakteri probiotik pencernaan manusia. Peningkatan konsentrasi propolis dapat menghambat pertumbuhan $B$. infantis secara signifikan melebihi kontrol. Namun, propolis hingga konsentrasi 0,8\% dapat menstimulasi pertumbuhan L. acidophilus. Interaksi beragam antara propolis dan bakteri probiotik menjadi alasan untuk mengetahui pengaruh propolis terhadap jenis-jenis bakteri alami pencernaan manusia yang juga digunakan sebagai starter pada produk minuman probiotik.

Penelitian ini bertujuan menguji pengaruh beberapa konsentrasi propolis Trigona spp asal Pandeglang Indonesia terhadap pertumbuhan dan produksi asam laktat tiga bakteri probiotik Lactobacillus casei subsp. rhamnosus, Streptococcus thermophilus, dan Lactobacillus delbrueckii subsp. bulgaricus pada susu. Walaupun penelitian mengacu pada Hadaddin et al. (2008) namun komposisi kimia propolis berbeda dari satu tempat dengan tempat lainnya demikian pula dengan keaktifannya. Hal tersebut yang menunjukkan perbedaan dengan penelitian yang dilakukan oleh Hadaddin et al. (2008) serta sesuai dengan Toreti et al. (2013) dan Monzote et al. (2012). Hasil penelitian ini diharapkan dapat digunakan sebagai acuan dalam pembuatan produk minuman probiotik yang difortifikasi dengan propolis.

\section{BAHAN DAN METODE}

\section{Bahan dan Alat}

Bahan-bahan yang digunakan adalah sarang lebah madu Trigona spp. asal Pandeglang, Banten, Indonesia, etanol 70\%, kultur bakteri $L$. casei subsp.rhamnosus, S. thermophilus, dan L.delbrueckii subsp. bulgaricus (diperoleh dari laboratorium mikrobiologi, Departemen Ilmu dan Teknologi Pangan, Fakultas Teknologi Pertanian, IPB), media MRS (de Man, Rogosa, Sharpe), media MRS agar, dan indikator fenolftalin (PP).

\section{Metode}

\section{Ekstraksi Propolis}

Sebanyak 200 g sarang lebah Trigona spp. dimasukkan dalam Labu Erlenmeyer 1000 mL dan direndam dengan $650 \mathrm{ml}$ etanol 70\% sambil dikocok di atas inkubator bergoyang. Setelah itu filtrat dirotaevaporasi hingga terbentuk pasta propolis bebas etanol yang disebut dengan ekstrak etanol propolis (EEP) (Hasan 2006). EEP ini sukar dilarutkan sehingga diperlukan penambahan stabilizer. Sebanyak $2.5 \mathrm{~g}$ propolis ekstrak padat dilarutkan dalam $50 \mathrm{~mL}$ akuades kemudian dipanaskan selama 20 menit pada suhu $45^{\circ} \mathrm{C}$. Setelah dingin, ditambahkan $0.4 \mathrm{~g}$ gum 
guar dan dihomogenasi. Prosedur ini dilakukan secara analitik sehingga konsentrasi akhir yang digunakan sebagai stok propolis adalah $5 \% \mathrm{~b} / \mathrm{v}$ (modifikasi dari Haddadin et al. 2008). Tata cara ekstraksi propolis ini sudah didaftarkan paten HAKI-nya (Hasan 2006; Haddadin et al. 2008).

\section{Penyiapan Bakteri Uji Penyiapan Media Tumbuh Bakteri}

Sebanyak $1.5 \mathrm{~g}$ bacto agar dan $5 \mathrm{~g}$ MRS dilarutkan dalam akuades $100 \mathrm{~mL}$ pada Labu Erlenmeyer $100 \mathrm{~mL}$ sambil dipanaskan 6 hingga homogen. Selanjutnya, media dituangkan sebanyak $5 \mathrm{~mL}$ ke dalam tabung reaksi, disumbat dengan kapas, dan disterilisasi dengan autoklaf suhu $121^{\circ} \mathrm{C}$ selama 15 menit. Setelah itu, media disimpan pada cetakan papan miring sampai memadat (Mitsuoka 1990).

\section{Peremajaan Kultur Bakteri}

Kultur bakteri L. casei subsp. rhamnosus, S. thermophilus, dan L. delbrueckii subsp. bulgaricus. Sebanyak satu ose bakteri dari media MRS agar miring digoreskan secara zigzag ke dalam media MRS agar miring yang baru dan diinkubasi pada suhu $37^{\circ} \mathrm{C}$ selama dua hari. Peremajaan dilakukan setiap dua minggu sekali secara rutin kemudian disimpan pada suhu $4{ }^{\circ} \mathrm{C}$.

\section{Pengukuran Optical Density/OD.}

Kultur biakan yang diremajakan adalah murni yang telah tumbuh dalam media agar miring diinokulasikan sebanyak satu ose ke dalam media MRS cair. Kemudian dilakukan pengukuran OD masing-masing bakteri menggunakan spektrofotometer pada panjang gelombang $600 \mathrm{~nm}$ sampai diperoleh nilai absorbansnya 0.500 .

\section{Pembuatan Kultur Starter Bakteri Uji}

Tiga botol fermentasi masing-masing diisi $50 \mathrm{~mL}$ larutan susu skim $(10 \% \mathrm{~b} / \mathrm{v})$ kemudian dipasteurisasi pada suhu $73{ }^{\circ} \mathrm{C}$ selama 30 menit. Setelah dingin (suhu $37^{\circ} \mathrm{C}$ ), setiap bakteri uji yang telah diukur $\mathrm{OD} \pm 0.500$ dan diinokulasikan ke dalam botol berisi susu dan diinkubasi selama 12 jam setelah tercapai suhu $37^{\circ} \mathrm{C}$. Lama waktu fermentasi tersebut merupakan fase logaritmik pertumbuhan bakteri asam laktat (Haddadin et al. 2008).

\section{Fermentasi Bakteri}

Sebanyak 2, 6, dan $10 \mathrm{~mL}$ propolis stok dilarutkan dalam susu skim 10\% (b/v) hingga volumenya mencapai $50 \mathrm{~mL}$. Susu dengan konsentrasi propolis $0.2,0.6$ dan $1.0 \%$ tersebut kemudian dipasteurisasi pada suhu 63 ${ }^{\circ} \mathrm{C}$ selama 30 menit. Setelah dingin (suhu 37 ${ }^{\circ} \mathrm{C}$ ), $500 \mu \mathrm{L}$ kultur starter diinokulasikan ke dalam susu dan diinkubasi pada suhu $37^{\circ} \mathrm{C}$ selama 18 jam. Sebagai kontrol digunakan susu tanpa penambahan propolis $(0 \%)$, dan sebagai pembanding digunakan propolis $\mathrm{X}$ (komersial) konsentrasi 0.4\% (Haddadin et al. 2008).

\section{Parameter Uji Analisis Total Bakteri Metode Total Plate Count (TPC)}

Sampel susu yang telah diinkubasi selama 18 jam dipipet sebanyak $1 \mathrm{~mL}$ dan dimasukkan ke dalam tabung reaksi yang berisi $9 \mathrm{~mL}$ larutan $\mathrm{NaCl} 0.85 \%$ sehingga didapatkan pengenceran $10^{-1}$ kemudian dikocok dengan vorteks. Selanjutnya pengenceran dibuat sampai $10^{-7}$ menggunakan larutan pengencer yang sama. Pemupukan dilakukan untuk pengenceran $10^{-5}$ sampai $10^{-7}$ pada cawan Petri berisi MRS agar. 
Cawan selanjutnya diinkubasi pada suhu $37{ }^{\circ} \mathrm{C}$ dengan posisi terbalik. Pemupukan dilakukan duplo untuk setiap pengenceran. Perhitungan koloni yang tumbuh dilakukan setelah 48 jam (Pelczar \& Chan 1988).

\section{Analisis Total Asam Tertitrasi}

Analisis total asam dilakukan pada sampel dengan konsentrasi optimum masingmasing bakteri uji dari hasil analisis TPC. Analisis dilakukan setiap 12 jam mulai jam ke-0, 12, 24, 32, 48, 60, dan 72. Sebanyak 10 $\mathrm{mL}$ sampel dipipet ke dalam Labu Erlenmeyer kemudian dititrasi dengan $\mathrm{NaOH} \quad 0.1 \quad \mathrm{~N}$. Indikator yang digunakan adalah fenolftalin 1\% dengan perubahan warna dari tidak berwarna menjadi merah muda. $\mathrm{NaOH}$ yang digunakan distandardisasi terlebih dahulu menggunakan asam oksalat $0.1 \mathrm{~N}$. Konsentrasi total asam tertitrasi dihitung sebagai persen asam laktat (AOAC 1995).

\section{Pengukuran pH}

Analisis $\mathrm{pH}$ dilakukan bersamaan dengan analisis TAT, yaitu setiap 12 jam mulai jam ke0, 12, 24, 32, 48, 60, dan 72. Sebanyak $10 \mathrm{ml}$ sampel yang akan dititrasi terlebih dahulu diukur nilai $\mathrm{pH}$ nya menggunakan indikator universal. Pengukuran dilakukan pada suhu ruang.

\section{Analisis Statistika}

Data yang diperoleh dari penghitungan jumlah koloni bakteri dianalsis menggunakan rancangan acak lengkap (RAL) untuk mengetahui pengaruh faktor perlakuan konsentrasi propolis terhadap pertumbuhan masing-masing bakteri. Percobaan dilakukan dengan lima taraf konsentrasi $(0.0,0.2,0.6$ dan $1.0 \%$, serta propolis X dengan konsentrasi $0.4 \%$ ). Setiap perlakukan dilakukan duplo.

\section{HASIL}

Pertumbuhan bakteri probiotik dihitung menggunakan metode analisis lempeng total (TPC) pada media MRS agar. Setiap koloni yang tumbuh dianggap berasal dari satu sel bakteri. Sampel yang dianalisis adalah bakteri probiotik tunggal yang ditumbuhkan selama 18 jam pada susu dengan variasi konsentrasi propolis. Perlakuan konsentrasi propolis yang diberikan adalah 0.2, 0.6 dan 1.0\%. Sebagai kontrol digunakan susu tanpa penambahan propolis dan sebagai pembanding digunakan propolis $\mathrm{X}$ konsentrasi $0.4 \%$. Hasil perhitungan disajikan pada Tabel 1. Data perubahan $\mathrm{pH}$ dan konsentrasi asam laktat yang diproduksi fermentasi dari tiga bakteri asam laktat disajikan pada Tabel 2. Produksi asam laktat selama fermentasi dari tiga bakteri asam laktat disajikan pada Tabel 3.

Tabel 1 Hasil perhitungan jumlah koloni bakteri asam laktat $\left(\mathrm{x} 10^{8}\right)$ akibat pemberian propolis.

\begin{tabular}{lccccc}
\hline \multirow{2}{*}{ Jenis Bakteri } & \multicolumn{5}{c}{ Konsentrasi Propolis (\%) } \\
\cline { 2 - 5 } & $\mathbf{0}$ & $\mathbf{0 . 2}$ & $\mathbf{0 . 6}$ & $\mathbf{1 . 0}$ & Propolis X (komersial) \\
\cline { 2 - 5 } & 25.17 & 3.78 & 1.34 & 0.47 & 0.70 \\
\hline L. bulgaricus & 6.57 & 15.53 & 24.73 & 10.85 & 18.45 \\
L. rhamnosus & 5.5 & 5.83 & 9.30 & 4.8 & 10.23 \\
S. thermophilus & \multicolumn{5}{c}{ Jumlah koloni bakteri asam laktat (x10 } \\
\hline
\end{tabular}


Tabel 2 Perubahan $\mathrm{pH}$ dan konsentrasi asam laktat yang diproduksi fermentasi dari tiga bakteri asam laktat.

\begin{tabular}{lcccccccc}
\hline \multirow{2}{*}{ Jenis Bakteri } & \multirow{2}{*}{ Contoh } & \multicolumn{7}{c}{ Pengukuran Jam ke- } \\
\cline { 3 - 8 } & & $\mathbf{0}$ & $\mathbf{1 2}$ & $\mathbf{2 4}$ & $\mathbf{3 2}$ & $\mathbf{4 8}$ & $\mathbf{6 0}$ & $\mathbf{7 2}$ \\
\hline Tidak Ada Bakteri (-) & Blanko & 8 & 8 & 6 & 6 & 5 & 5 & 5 \\
L. bulgaricus & Kontrol 0 & 8 & 6 & 6 & 5 & 5 & 5 & 5 \\
& Contoh 0.2 & 8 & 6 & 5 & 5 & 4 & 4 & 4 \\
L. rhamnosus & Kontrol 0 & 8 & 6 & 5 & 5 & 4 & 4 & 4 \\
& Contoh 0.6 & 8 & 6 & 5 & 5 & 4 & 4 & 4 \\
L. thermophilus & Blanko & 8 & 7 & 7 & 7 & 5 & 5 & - \\
& Kontrol 0 & 7 & 6 & 6 & 5 & 5 & 4 & - \\
& Contoh 0.6 & 7 & 6 & 5 & 5 & 4 & 4 & - \\
\hline
\end{tabular}

\section{PEMBAHASAN}

\section{Pertumbuhan LCR}

Pertumbuhan LCR memiliki respon yang berbeda nyata $(\mathrm{p}<0.05 \%)$ dari perlakuan konsentrasi propolis (Tabel 1). Adanya propolis pada konsentrasi $0.2-1.0 \%$ menyebabkan jumlah bakteri yang tumbuh menjadi lebih tinggi daripada kontrol. Aktivitas propolis dalam memicu pertumbuhan ini diduga karena adanya kandungan gula (polisakarida) dan beberapa kelompok asam amino yang ikut terekstrak bersamaan dengan senyawa aktif propolis. Hal ini karena propolis mengandung berbagai macam bahan diantaranya hidrokarbon, polisakarida, asam amino dan bahan lain. Propolis juga terdeteksi mengandung glukosa (Abd El Hadi dan Hegazi 2002, Greenaway et al. 1990, Marcucci 1995).
Menurut Tamime dan Robinson (2007), bakteri probiotik kelompok Lactobacillus casei dapat memfermentasi berbagai macam gula untuk memacu pertubuhannya. Pada penelitian ini, konsentrasi propolis sebesar $0.2 \%$ dan 0.6 $\%$ tidak menghambat pertumbuhan bakteri ini. Tapi pada konsentrasi yang lebih tinggi dari 0.6 $\%$ atau $1.0 \%$ terjadi penghambatan pertumbuhan bakteri LCR walaupun tidak berbeda nyata dengan kontrol. Hasil tersebut berbeda dengan yang dilakukan oleh Tukan (2008) bahwa konsentrasi propolis yang dapat memberikan efek penghambatan adalah $4.17 \%$. Hal ini terjadi mungkin karena perbedaan metoda uji aktivitas antibakteri. Sesuai dengan pendapat Tamime dan Robinson (2007) bahwa residu antibiotik dalam susu dapat mempengaruhi viabilitas kultur bakteri namun aktivitasnya lebih rendah dibandingkan dengan dalam media lain.

Tabel 3 Produksi asam laktat selama fermentasi dari tiga bakteri asam laktat.

\begin{tabular}{lcccccccc}
\hline \multirow{2}{*}{ Jenis Bakteri } & \multirow{2}{*}{ Contoh } & \multicolumn{7}{c}{ Pengukuran Jam ke- } \\
\cline { 3 - 8 } & & $\mathbf{0}$ & $\mathbf{1 2}$ & $\mathbf{2 4}$ & $\mathbf{3 2}$ & $\mathbf{4 8}$ & $\mathbf{6 0}$ & $\mathbf{7 2}$ \\
\hline \multirow{2}{*}{ L. bulgaricus } & Kontrol 0 & -0.02 & 0.1 & 0.03 & 0.07 & 0.12 & 0.25 & 0.29 \\
& Contoh 0.2 & 0 & 0.17 & 0.04 & 0.09 & 0.16 & 0.36 & 0.52 \\
\multirow{2}{*}{ L. rhamnosus } & Kontrol 0 & -.02 & 0.16 & 0.08 & 0.09 & 0.14 & 0.25 & 0.32 \\
& Contoh 0.6 & 0.01 & 0.15 & 0.02 & 0.01 & 0.03 & 0.12 & 0.12 \\
\multirow{2}{*}{ L. thermophilus } & Kontrol 0 & 0 & 0.14 & 0.03 & 0.16 & 0.17 & 0.18 & - \\
& Contoh 0.6 & 0.03 & 0.16 & 0.10 & 0.25 & 0.26 & 0.28 & - \\
\hline
\end{tabular}


Hasil uji Duncan menunjukkan bahwa perlakuan konsentrasi propolis yang paling berbeda nyata $(p<0.05)$ adalah konsentrasi 0.6 $\%$. Pada konsentrasi ini, propolis menstimulasi pertumbuhan LCR paling tinggi $\left(24.725 \times 10^{8}\right.$ $\mathrm{sel} / \mathrm{ml})$ melebihi kontrol tanpa propolis $(6.575$ x $10^{8} \mathrm{sel} / \mathrm{ml}$ ). Konsentrasi propolis $0.6 \%$ ini selanjutnya digunakan sebagai acuan untuk uji produksi asam laktat dan pengukuran $\mathrm{pH}$. Sebagai kontrol, digunakan juga sampel konsentrasi $0.0 \%$.

\section{Pertumbuhan STP}

Pertumbuhan bakteri STP memiliki respon yang tidak berbeda nyata $(\mathrm{p}<0.05)$ dari semua perlakuan konsentrasi propolis (Tabel 1). Hal ini menunjukkan adanya propolis dalam medium fermentasi tidak mempengaruhi pertumbuhan bakteri tersebut. STP merupakan bakteri yang sensitif terhadap residu antibiotik, namun beberapa galur dari STP mempunyai sensitifitas yang lebih rendah dibandingkan dengan LDB (Tamime dan Robinson 2007). Hal ini sesuai dengan hipotesa bahwa ada LAB yang dapat bertahan dengan adanya penambahan propolis pada konsentrasi tertentu. Hal ini memberikan pencerahan dalam peran propolis dalam memberikan fortifikasi antibiotik dalam pangan untuk melawan bakteri patogen, sehingga menumbuhkan peran antioksidan dan anti kanker dari propolis tersebut. Berbeda dengan hasil uji statistika $(\mathrm{p}<0.05)$, berdasarkan data Tabel 1, pertumbuhan STP dalam medium fermentasi dengan konsentrasi 0.6 dapat merangsang pertumbuhan bakteri dibandingkan dengan kontrol $\left(9.3 \times 10^{8} \mathrm{sel} / \mathrm{ml}\right.$ dibandingkan dengan $\left.5.5 \times 10^{8} \mathrm{sel} / \mathrm{ml}\right)$, demikian pula halnya dengan propolis X dapat memacu pertumbuhan bakteri STP pada jumlah $10.225 \mathrm{sel} / \mathrm{ml}$.

\section{Pertumbuhan LDB}

Pertumbuhan bakteri LDB sangat dipengaruhi oleh adanya propolis dalam media fermentasinya (Tabel 1). Respon yang diberikan oleh bakteri ini berbeda dengan dua bakteri sebelumnya. Makin tinggi konsentrasi propolis makin rendah pertumbuhan bakteri LDB. Pertumbuhan tertinggi terjadi pada kontrol dan konsentrasi propolis terendah, dengan bertambahnya konsentrasi propolis makin rendah pula pertumbuhan bakteri LDB. Hal ini membuktikan bahwa propolis mempunyai senyawa aktif yang dapat menghambat pertumbuhan LDB. Hasil tersebut sesuai dengan penelitian Hadaddin et al (2008) bahwa propolis dapat menghambat bakteri Bifidobacterium infantis. Berdasarkan uji lanjut Duncan perlakuan dengan propolis menunjukkan pengaruh yang berbeda dengan kontrol.

\section{Produksi asam laktat dan perubahan $\mathrm{pH}$ media}

Pengamatan pola produksi asam laktat (setara dengan jumlah asan total yang tertitrasi) dilakukan terhadap konsentrasi optimum propolis yang diperoleh dari pengamatan pertumbuhan (Tabel 3). Bakteri LCR optimum pada konsentrasi $0.6 \%$, STP pada konsentrasi $0.6 \%$ dan LDB pada konsentrasi $\quad 0.2 \%$. Konsentrasi propolis tersebut merupakan konsentrasi yang menunjukkan pertumbuhan bakteri-bakteri tersebut tertinggi sehingga diharapkan pola produksi asam laktat juga paling tinggi.

Asam laktat diukur menggunakan metode analisis titrasi total asam. Bahan yang dianalisis adalah contoh media yang sudah diberi perlakuan propolis dan blanko (susu murni tanpa propolis dan starter bakteri) serta kontrol (fer- 
mentasi susu dengan starter tanpa propolis). Pengukuran asam laktat dilakukan setiap selang 12 jam mulai dari jam ke-0 hingga jam ke-72. Pengamatan hingga jam ke-72 diharapkan untuk mengetahui pola produksi asam laktat selama penyimpanan. Perubahan produksi asam laktat berhubungan dengan perubahan tingkat kemasaman media $(\mathrm{pH})$. Pengukuran $\mathrm{pH}$ dilakukan bersamaan dengan pengukuran jumlah asam laktat.

Fermentasi susu oleh masing-masing bakteri uji menyebabkan penurunan $\mathrm{pH}$ dan menghasilkan pola produksi asam laktat yang fluktuatif tapi cenderung meningkat (Tabel 2). Kenaikan asam laktat dalam konsentrasi rendah dapat berpengaruh terhadap laju disosiasi ion $\mathrm{H}^{+}$ sehingga berakibat pada perubahan $\mathrm{pH}$ media (Walstra et al. 1999). Pada awalnya, kenaikan asam laktat diikuti dengan penurunan $\mathrm{pH}$, tapi setelah jam ke-48 kenaikan total asam laktat tidak selalu diikuti dengan penururan $\mathrm{pH}$.

Kurva produksi asam laktat mengalami peningkatan pada jam ke-12 kemudian menurun pada jam ke-24. Menurut Tamime dan Robinson (2007), selama fermentasi susu pada jam ke12 hingga jam ke-18 akan menghasilkan asam laktat yang tinggi dengan kualitas fisik susu fermentasi yang baik. Pada tahap ini bakteri akan memproduksi asam laktat dari laktosa sebagai sumber utama atom karbon. Setelah itu, bakteri akan menggunakan sumber karbon cadangan yang lain sehingga terjadi penurunan total asam laktat dan paling rendah terjadi pada jam ke24. Pada jam berikutnya, asam laktat mengalami kenaikan hingga pengukuran terakhir (jam ke-72). Hal ini sesuai dengan hasil penelitian Ramadzanti (2006) dan Kusnawati (2004) bahwa kadar asam laktat dalam fermentasi susu (yoghurt) makin meningkat dengan makin lamanya penyimpanan, namun secara kualitas yogurt makin menurun. Hal ini disebabkan karena monosakarida dan asam amino dalam media digunakan untuk memproduksi asam laktat.

Penambahan propolis ke dalam susu menurunkan produktivitas asam laktat bakteri LCR dan menstimulasi produksi asam laktat bakteri LDB dan STP. Pola perubahan $\mathrm{pH}$ pada LCR antara kontrol dan perlakuan pemberian propolis tidak menunjukkan perbedaan yang nyata (Gambar 2b). Keduanya memiliki nilai pH yang sama pada setiap pengukuran. Hal ini menunjukkan adanya propolis tidak mempengaruhi perubahan $\mathrm{pH}$ bahkan perubahan jumlah asam laktat menunjukkan jumlah yang lebih rendah dibandingkan dengan kontrol. Pada fermentasi susu menggunakan propolis $0.6 \%$ dapat meningkatkan pertumbuhan bakteri LCR dan tidak meningkatkan jumlah asam laktat atau perubahan $\mathrm{pH}$ yang dialami hampir sama pola nya dengan kontrol.

Nilai $\mathrm{pH}$ yang diukur pada fermentasi LDB menunjukkan penurunan $\mathrm{pH}$ sesuai dengan laju kenaikan jumlah asam laktat. Laju penurunan $\mathrm{pH}$ terus terjadi hingga mencapai pH 4 pada akhir masa inkubasi (jam ke-72), demikian pula dengan laju kenaikan asam laktat terus terjadi. Hal ini menunjukkan pengaruh bahwa penambahan propolis dapat meningkatkan produksi asam laktat bakteri LDB yang disertai dengan penurunan $\mathrm{pH}$ media. Namun pada inkubasi setelah jam ke-60 peningkatan jumlah asam laktat menunjukkan fase logaritmik. Sedangkan pada kondisi (jam ke-60) tersebut perubahan $\mathrm{pH}$ media sudah stabil di angka pH 4. Pada fermentasi susu dengan bakteri LDB dan penambahan propolis sebanyak $0.2 \%$ dapat meningkatkan produksi asam laktat yang sangat nyata setelah jam ke-60 dengan $\mathrm{pH}$ yang stabil setelah jam ke-48. 
Pola produksi asam laktat dan perubahan pH yang sama dengan LDB dialami oleh penambahan bakteri STP. Jumlah total asam laktat terus meningkat sesuai dengan bertambahnya waktu fermentasi. Perubahan $\mathrm{pH}$ mengalami konsisi stabil setelah jam ke-48. Pada fermentasi susu dengan bakteri STP dan penambahan propolis sebanyak $0.6 \%$ dapat meningkatkan produksi asam laktat yang sangat nyata setelah jam ke-60 dengan $\mathrm{pH}$ yang stabil setelah jam ke-48.

Menurut Walstra et al (1999), jumlah asam laktat yang disarankan dalam produk susu fermentasi jumlahnya sekitar 0.7-0.9 \% (b/b). Hal ini akan berpengaruh terhadap kegiatan bakteri dalam saluran pencernaan manusia. Sementara itu, dalam saluran pencernaan manusia, asam laktat diproduksi dari berbagai substrat melalui fermentasi bakteri usus. Produk fermentasi dari LAB memiliki peran penting dalam kesehatan dan keseimbangan mikroflora saluran pencernaan (Topping dan Clifton 2001). Dari penelitian ini diketahui bahwa, meskipun propolis dikenal memiliki manfaat kesehatan sebagai antibakteri, namun propolis pada konsentrasi tertentu dapat memiliki peranan sinergik dengan bakteri probiotik sehingga perlu ditambahkan pada produk fermentasi susu baik sebagai substrat bakteri maupun untuk mendapatkan manfaat lain dari propolis.

Berdasarkan penelitian ini, propolis asal Trigona spp dapat menstimulasi pertumbuhan bakteri Lactobacillus casei subsp. rhamnosus namun menghambat produksi asam laktat. Peningkatan produksi asam laktat terjadi pada fermentasi susu yang diinokulasi bakteri Streptococcus thermophilus, dan Lactobacillus delbrueckii subsp. bulgaricus dengan penambahan propolis masing-masing sebanyak $0.6 \%$ dan 0.2
\%. Pada fermentasi susu dengan menggunakan kedua bakteri tersebut kondisi $\mathrm{pH}$ mengalami fase stabil setelah jam ke-48.

\section{DAFTAR PUSTAKA}

[AOAC] Association of Official Analytical Chemistry. 1995. Official Methods of Analysis. Washington

Bankova VS, de Castro SL, Marucci MC. 2000. Propolis: Recent advances in chemistry and plant origin. Apidol 31: 3-15.

Fatoni A. 2008. Pengaruh propolis Trigona spp. asal Bukit tinggi terhadap beberapa bakteri usus halus sapi dan penelusuran komponen aktifnya [tesis]. Bogor: Sekolah Pascasarjana, Institut Pertanian Bogor.

Fearnley J. 2001. Bee Propolis Natural Healing from The Hive. London: Souvenir Pr.

Greenaway W, Scaysbrook T, Whatley FR. 1990. The composition and plant origins of propolis: A report of work at Oxford. Bee World 71: 107-18.

Haddadin MSY, Nazer I, Abu Raddad SJ, Robinson RK. 2008. Effect of propolis on two bacterial species with probiotic potential. Pakist $J$ Nutr 7: 391-394.

Hasan AEZ. 2006. Potensi propolis lebah madu Trigona spp. sebagai zat antimikrobial [laporan hasil penelitian]. Bogor: Lembaga Penelitian dan Pengabdian Masyarakat Institut Pertanian Bogor.

Kalogeropoulos N, Konteles S, Troullidou E, Mourtzinos I, Karathanos VT. 2009. Chemical composition, antioxidant activity and antimicrobial properties of propolis extracts from Greece and Cyprus. Food Chem. xxx (2009) xxx-Xxx. (Artikel diperoleh dari Pengarang).

Kusnawati Y. 2004. Aktivitas protease susu pateurisasi yang ditambah Bifidobacterium bifidum pada berbagai waktu simpan [skripsi]. Bogor: Fakultas Matematika dan Ilmu Pengetahuan Alam, Institut Pertanian Bogor.

Marcucci MC. 1995. Propolis: chemical composition, biological properties and therapeutic activity. Apidol 26: 83-99. 
Mitsuoka T. 1990. A Profile of Intestinal Bacteria. Tokyo: Yakult Honsha. Oxoid. 1980. The Oxoid Mannual of Culture Media, Ingredients, and Other Laboratory Practise. Ed ke-5. Basingtoke: Oxoid.

Monzote L, Cuesta-Rubio O, Fernandez MC, Hernandez IM, Fraga J, Perez K, Kerstens $\mathrm{M}$, Maes L, Cos P. 2012. In vitro antimicrobial assessment of Cuban propolis extracts. Mem Inst Oswaldo Cruz. 107(8):978-984.

Pelczar MJJr, Chan ECS. 1988. Dasar-Dasar Mikrobiologi. Volume ke-1,2. Hadioetomo RS, Imas T, Tjitrosomo SS, Angka SL, penerjemah; Jakarta: UI Pr. Terjemahan dari: Elements of Microbiology.

Ramadzanti A. 2006. Aktivitas protease dan kandungan asam laktat pada yoghurt yang dimodifikasi Bifidobacterium bifidum [skripsi]. Bogor: Fakultas Matematika dan Ilmu Pengetahuan Alam, Institut Pertanian Bogor.

Sabir A. 2005a. Aktivitas antibakteri flavonoid propolis Trigona sp. Terhadap bakteri Streptococcus mutans (in vitro). Dent J38: 135-141.

Sabir A. 2005b. Respons inflamasi pada pulpa gigi tikus setelah aplikasi ekstrak etanol propolis (EEP). Dent J 38: 77-83.

Sulminen S, Ouwehana A, Benno V, Lee YK. 1999. Probiotik: How Should They be Defined. Trend in Food Science and Technology. Ed ke-10. Norfolk: Horison Scientific Pr.

Tamime AY, Robinson RK. 2007. Yoghurt, Science, and Technology. Ed ke-3. New York: CRC $\operatorname{Pr}$

Topping DL, Clifton PM. 2001. Short-chain fatty acids and human colonic function: Roles of resistant starch and non-starch polysaccharides. Physiol Rev 81: 1031-1064.

Toreti VC, Sato HH, Pastore GM, Park YK. 2013. Recent Progress of Propolis for Its Biological and Chemical Compositions and Its Botanical Origin. Evid Based Complement Alternat Med. Article ID 697390:13.

Tukan GD. 2008. Pengaruh propolis Trigona spp asal Pandeglang terhadap beberapa isolat bakteri usus sapi dan penelusuran komponen aktifnya [tesis]. Bogor: Sekolah Pascasarjana, Institut Pertanian Bogor.

Walstra P, Geurts TJ, Noomen A, Jellema A, Boekel MAJS. 1999. Dairy Technology. Principless of Milk Properties and Processes. New York: Marcell Dekker. 